\section{History \\ Education \\ Research \\ Journal}

\title{
A report on Greek history education
}

\section{George Kokkinos* - University of the Aegean, Greece}

The editors of the History Education Research Journal are delighted to include a brief report on Greek history education from Professor George Kokkinos, in which he provides a context for the papers from Greek history education researchers featured in this issue, and offers information about the vibrant Greek history education community.

On 3 June 2019, the new Greek history curriculum was approved by the Ministry of Education and became statutory. The curriculum was constructed over three years by a group of academic and specialist historians, history education experts and teachers.

The aim of the Greek history curriculum project (2016-19) was to synchronize history education in Greece with the Western paradigm, particularly with the AngloSaxon school of history didactics. However, history education in Greece progresses slowly due to the belief that any reformation in accordance with international developments would be unacceptable to a large portion of Greek society, including many members of the political and media establishment.

Nevertheless, the recently institutionalized new history curriculum constitutes an attempt to completely reorganize the cognitive and value-centred content of the syllabus, starting from the third grade of primary school (dimotiko), 8-9 year olds, up to the second and final grade of senior high school (lyceum), 16-17 year olds. (There are four grades of primary school (ages 6 to 11), three of junior high (gymnasium, ages 12 to 15) and two of senior high (ages 15 to 17)). In the new history curriculum, the cognitive and value-centred content of history teaching serves the following main goals:

- the development of historical thought

- the development of genetic historical consciousness according to Jörn Rüsen's theory

- the conceptualization of the nation as a historically formed entity that is open and inclusive, and not as a hyper-historical category

- the cultivation of democratic citizenship

- the shift of content from national history towards European and world history.

Teaching history is now linked to educational practices referring to the second-order syntactic concepts of history - that is, drawn from history as an academic discipline with discrete procedures, protocols, skills and processes. We could even say that the state monopoly of the production and social diffusion of historical knowledge, which was standard practice from the fascistic 4th of August Regime (1936-41) until the present, is - to some degree - abolished. More specifically, the 2019 curriculum encourages the community of teachers and students to include many serious aspects of public history in their school history, as well as to incorporate academic historiography as an appropriate educational tool, under certain educational conditions.

In spite of the spasmodic but brave steps taken since 1974, as far as the reconstruction of Greek historical identity is concerned, Greece remains a country whose historical culture has been stigmatized by a fixation on the glorious past of the ancient Greeks and the Byzantine emperors, as well as by the nation's perception of 
itself as the chosen one, its destiny being to resist every conspiracy, while its historical mission is to 'civilize' its 'inferiors'.

Consequently, younger generations in Greece remain largely ideologically indoctrinated. This is due to many agents, especially during times of political crisis: the political parties and state policies, still divided by the Civil War (1946-9); the Orthodox Church; the groups that constructed their collective identities upon historical traumas after the 1922 national catastrophe of defeat in the Greco-Turkish War and the subsequent internal strife; and the media and the emergence of the virtual digital communities of the internet.

These elements create a rigid context over which political intent, state legislation and the opinions of specialists have no power. That is to say, the radical move to introduce the new curriculum could be in vain while school textbooks have not been renewed and teachers have not been specially trained. Within this conjunction of events, at a time when the new government of New Democracy (Nea Dimokratia) of July 2019 bring a serious danger of conservative restoration, this could turn the subject of the new curriculum into an arena of political dispute, thus creating another 'symbolic war', as happened in 2002 and 2006/7.

It should also be noted that the community of professional historians in Greece is quite large. However, although there are at least three important research journals ( $T a$ Istorika, Mnemon and Historein) linked to the revitalization of history studies in Greece, and in spite of the significant progress made in Greek historiography since 1974, a large percentage of the educated public and, most importantly, of teachers are still supporters of ideologically constructed narratives. And they have not made any effort, especially during the recent long period of political crisis, to keep up with the frequent innovative epistemological and research developments that have taken place. Thus, the gap between academic research and public opinion is constantly widening. At the same time, during the last decade, history didactics has significantly improved its position in the institutional hierarchy of history studies. This is especially true for university departments, where future primary education teachers are currently trained.

History education in Greece is constantly enriched with substantial works, keeping up with international research developments. New topics make their appearance alongside the major focuses of history education research upon history curricula and textbooks, aiming to reduce assumptions, stereotypical thinking and political hostility between people. Some examples of research include:

- the study of historical culture and public history (mostly regarding cinema and oral history)

- comparative inter-state history education

- teachers' and students' attitudes and perceptions

- historical concepts

- the emphasis on historical skills and competences

- the correlation between material culture and history education

- the use of new technologies and media (with an emphasis on online games)

- the exploration of controversial and traumatic events or taboo topics.

Representatives of this new trend include the curricula of the numerous Greek university primary education departments (but unfortunately not those of their history departments) and of several master's degree programmes, such as the MA of the Open Hellenic University in public history; the MA in historical research, didactics and new technologies at Ionian University (Corfu); and the MA in museology and cultural 
management at the Aristotle University of Thessaloniki with the collaboration of the Department of Primary Education at the University of Western Macedonia.

Important exponents of this modernizing spirit in history didactics also include:

- the magazines Themata Istorias tis Ekpaideusis (Issues on History of Education), published by the Greek Community of Historians of Education, and Nea Paideia (New Education)

- the Association for Historical Education in Greece (AHEG), which is composed of professionals specializing in history didactics, and which cooperates with EUROCLIO (European Association of History Educators) and the Council of Europe

- the Museum of the History of Education (Xeniseum), founded and managed by Professor Antonis Chourdakis of the Department of Primary Education at the University of Crete (Rethymnon).

The three Greek papers published in this issue reflect crucial aspects of the reformation process of historical education in Greece, in regard to the new curricula and the approach to controversial and traumatic historical events. On the other hand, the paper by Lukas Perikleous demonstrates that, although the ideological and political rigidity in Cyprus is yet to be overcome, similarly to Greece there is a strong network of new researchers on the island, with an organic connection to the British school of history didactics. What is more, the overall topics of their research are at the core of the interests of the international academic community.

\section{Notes on the contributor}

George Kokkinos is Professor of History and History Didactics at the University of the

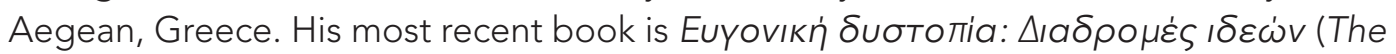
Dystopia of Eugenics: Trajectories of ideas), published in 2018 by Thines. 